\title{
The Effect of Freight Transport Service Performance on Global Market Competitiveness
}

\section{Eyakem Fikru}

Department of Mathematical statistics, Faculty of Information and Informatics Technology (Data Science), Kazan Federal University, Kazan and Postcode 420010, Russia

\begin{tabular}{|c|c|c|c|}
\hline Received: 02.06.2021 & Accepted: 15.06 .2021 & Published: 09.10.2021 & $\begin{array}{ll}\text { - } & \text { Final Version: 09.10.2021 }\end{array}$ \\
\hline
\end{tabular}

\begin{abstract}
The producers, intermediaries, shippers, and consignees, located often thousands of miles distant from each other, require efficient transport and logistics services to get the right product with the right quality and quantity to the right place within the right time and above all at a right price. The main objective of this study was to assess the effect of freight transport service performance on global market competitiveness. A descriptive research design was used. Secondary data were collected from international organizations' policies, standards documents, and annual reports of the year 2018 by using the Logistic Performance Index rank. Moreover, a quantitative research approach was applied. The data were entered, manipulated, organized, and analyzed using Excel and Statistical Package for Social Science. Both descriptive and inferential analyses were used to identify and examine the extent of international trade competitiveness and its implication in the global market. As the result reviled, the entire logistic performance factors such as Growth Domestic Product, Distance, Infrastructure, Landlocked, and Timelines were found to be significantly important to determine the global market competitiveness. But, the geographical distance between bilateral countries affected a country's trade negatively. The top 10 higher Logistic Performance Index scores more competitive and better implementer of the effects of freight transport factors; whereas, the bottom scorers had an ineffective market link with their partners.
\end{abstract}

Keywords: International trade; Global Competitiveness; Logistic Performance Index; Freight transport service; Growth Domestic Product.

\section{Introduction}

Transportation is an essential part of human activity and in many ways forms the basis of all socioeconomic interactions. Any kind of freight transport services are essential to support economic growth and development. The transportation industry for any country means promoting social and economic life; it enriches trade whereby the country's manufacturing industrial products, tourism, liquid products, and distribution. Therefore, effective and efficient transport operation practice increases the country's economic development and strategic roles in the national as well as global economic development.

The advancement in transport, logistics, and communication technologies has revolutionized total manufacturing, value-adding, and distribution, as well as the consumption process, and the world has become virtually a global village. Thus, the first and most important task for a transport carrier or a logistics service provider is to provide the best possible customer-oriented service for a well- balanced price and quality ratio (Wiegmans, Nijkamp \& Masurel, 2001). Consequently, the globalization of trade has been dependent on the transport system with factors such as quality, cost, and time (Banomyong \& Beresford, 2001). 
According to Konings, Priemus, Nijkamp, and Edward Elgar (2008), the importance of freight transport services is mainly functioning in both national and global economies is clear but transport volumes are eternally growing and the problems of accommodating the freight flow efficiently and sustainably are a real challenge. Traffic congestion is rapidly growing, and lead-time delay is happening, the service quality of freight transport couldn't satisfy the increasing demand of customers. The performance of the system affects public policy concerns like air quality, environmental, resource consumption, social equity, land use, urban growth, economic development, safety, security, and finally, exposure to trade costs. Considering these problems, there is a great challenge to achieve a breakthrough in the performance of freight transport systems.

The roles of transportation service sectors, their social benefits, and the countered problems in the world economy are better recognized, from the above-mentioned studies; whereas, the challenge of transport service and trade simplifications, need more emphasis and study. There is no adequate study on the sub-sector and although significant advances have been made to allow the transport industry trends with international trade as a whole. In that regard this study tried to answer the questions of how competitive are the timelines, GDP, Landlocked, infrastructure, and distance of freight transport service performance and international trade; and evaluate the extent of international trade competitiveness and its implications in the global market.

Moreover, the main aim of this study was to assess the effect of freight transport service performance on the global trade competitiveness under the specific objectives of identifying the effect of freight transport service in terms of timeline, GDP, landlocked, infrastructure, and distance on international trade competitiveness; and examining the extent of international trade competitiveness and its implications in the global market.

This study is organized with five sections. The first section describes the introduction of the study, the research problem, research question, objectives, and organization of the study included. Section two reviews the literature which leads to the development of conceptual framework. Section three also deals with the method of the study. Sources of data and variables, methods of data analysis are described in this part. The fourth section explains the data analysis, presentation, and interpretation of the finding. Conclusion is covered in the fifth section.

\section{Literature Review}

Transportation service helps to shape, promote a nation's economic health and quality of life. Not only does the transportation service provider for the mobility of people and goods, but it also influences patterns of growth and economic activity by providing access to land. According to Regan and Garrido (2001) the transportation of freight among countries internationally involves complex structures in a long-distance transportation system. It involves many stakeholders such as shippers, carriers, thirdparty logistic providers, consignees, seaports, airports, and multiple modes of transport service. Freight transportation improvements thus enable competitiveness by improving the productivity of one country. Increased competitiveness creates opportunities for business growth and expansion. The effect of freight and other market competitiveness is measured with basic factors such as GDP, Timelines, Landlocked, Infrastructure, and Distance.

\subsection{GDP}

From a global perspective, the movement of commercial trade across the globe has witnessed a wellcoordinated transport network through economic liberalization making it possible for firms in the industrial and retail sector to register tremendous growth, with particular reference to the developed countries. Over the years, most developed countries have been able to grow their economies through the network of the global village approach where importers and exporters from Europe, China, Asia, the Middle East, Japan, and Africa interact online and establish business deals that involve moving 
a large volume of trade using several modes of transport consolidated by several players such as freight forwarders. Transport logistics operations determine the efficiency of moving products to international markets irrespective of distance so long as it is well-coordinated and is moved with speed, reliability, and in the most cost-effective manner (Tseng, Yue, \& Taylor, 2005).

The movement of goods and services across borders has grown tremendously in recent years accounting for over $45 \%$ of the world GDP in 1990 up to date from $25 \%$ in 1970 . There was also a rapid shift to higher value-added activities: the export share of manufactures in developing countries tripled between 1970 and 1990 from 20 to 60\% (Mauro, 2018).

World trade expanded nearly thirty-fold in three decades since 1960. Manufactured goods as a percentage of total world exports increased from 55\% in 1980 to $75 \%$ in 1990 . The share of the Newly Industrialized Countries (NICs) manufactured exports that can be classified as "high tech" soared from 2\% in 1964 to 25\% in 1985. Export accounted for 22\% of GDP in East and Southeast Asia, 11\% for South Asia, and $10 \%$ for Latin America (Jesudason, 2020).

\subsection{Timeline}

Timeliness is the frequency with which shipments reach consignees within scheduled or expected delivery times. Transit time is correlated with cost. Shorter transit time provided by for instance air will result in a higher cost, and longer transit time provided by for instance rail is less expensive. Shorter transit time will however provide the supply chain with operations with less need for inventory and fewer backorders, leading to lower costs of the material flow. Backorders can be a result of a longer transit time as there is a correlation between transit time and the order quantity when replenishing the inventory. Time is weighed as the next most important criterion especially by the transportation provider as the gains of fast transportation are more to the advantage of the provider than the purchaser. Additionally, the time criterion is rated higher for high-value goods over short distances (Feo-Valero, Espino-Espino \& García-Menéndez, 2011).

\subsection{Landlocked}

Landlocked countries face serious challenges in managing transport logistics. According to the research of Faye, McArthur, Sachs, and Snow (2004), several factors are preventing landlocked African countries from faster development. The ability of landlocked countries to trade is affected by high trade costs. Most landlocked developing countries are very poor. Several landlocked developing countries are even moving further away from reaching their objectives.

The transportation cost incurred by a country when importing goods varies from a few percent of the value of trade, up to 30-40\% for the most remote and landlocked countries. And the consequences of this high transportation cost are: using scarce resources and choking off-trade (Henderson, Shalizi \& Venables, 2001).

The majority of landlocked countries usually face serious challenges in managing transport logistics. The provision of predictable, reliable, and cost-effective transport logistics is constrained due to deficiencies in road and rail infrastructure, inefficient port, and transit border operations that contribute to very high transport costs. The first leading transport mode of those countries is road (Rabiy, \& Edward, 2016).

\subsection{Infrastructure}

Infrastructure is treated separately, due to those features that distinguish it as an input and most of the specifications allow the use of physical stocks. Alternatively, infrastructure can be treated as total factor productivity augmenting input: by lowering the costs of production like through the costs of transport and communication, it increases the technological index. The World Economic Forum and Global Alliance for Trade (2016) suggested that improving key components can result in an increase 
of up to $4.7 \%$ in GDP and $14.5 \%$ in global trade respectively. This supports the argument by (Arvis et al., 2018) that better logistics spur growth, competitiveness, and investment.

Infrastructure which is utilized by some logistics transportation like the road is governmentally funded and provided free of charge in many countries. This is slowly changing as road user charges are introduced in several countries, like Germany. The charges are aimed at recovering capital and maintenance costs. The direct financing, planning, and provision of road infrastructure are controlled by the public sector rather than the market (Baird, 2007). So, this indicates that infrastructure is one of the basic driven factors for the logistic service improvement of one country.

\subsection{Distance}

The marine transport sector has the largest shares of global merchant trade which expect to cover 90 $\%$ of international business volume. Large shipping lines move a huge volume of trade between ports and are complemented by hinterlands intermodal transport services such as rail, road, and inland waterways (Grosso et al., 2014). Much as the marine transport sector is relatively cheaper in terms of shipping goods, the movement of goods from ports to the hinterland in terms of costs is rather prohibitive. The study found in WTO-Economic Research and Statistics Division (2019) illustrated that shipping a car from Japan to Abidjan could cost \$1,005 inclusive of insurance, while the cost of moving the same unit from Addis Ababa to Abidjan would cost \$500. The price difference occurred due to the distance variation other than the mines of transport too. The longer the distance incurs much cost than the shorter counterpart.

Further in the discussion on impacts of delay on trade, Hummels, and Schaur (2012) argued that a day in transit is an ad valorem tariff of 0.6-2.3\%. Investigating further, the study findings Hausman, Lee, and Subramanian (2012) found by calculation, that a 1\% reduction each in the distance and processing time measures would be associated with an increase of $1.39 \%$ and $0.373 \%$ respectively, in bilateral trade, and that a $1 \%$ reduction each in the total costs related to trade and in variability, would translate to an increase of $0.49 \%$ and $0.24 \%$ respectively, in bilateral trade.

\subsection{Conceptual framework}

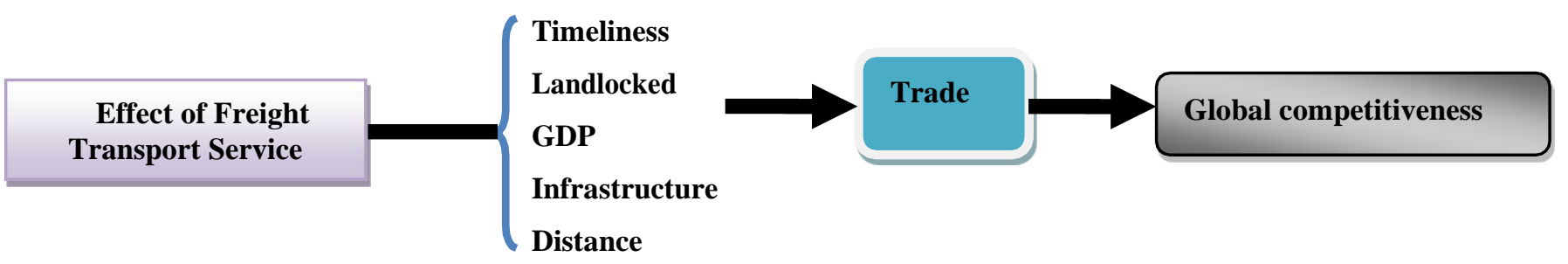

Figure 1. Conceptual framework

\section{Method of the Research}

Since the study aimed to evaluate the effect of freight transport service performance on the international trade competitiveness, the type of data for the study was more quantitative in nature; so that it could be measured and ranked. So, to arrange the conditions for the collection and analysis of data in a manner that aims to combine relevance with the research purpose, the study used a descriptive research design. Moreover, to achieve the objectives of this study and thereby to give an answer to its problems, a quantitative research approach had been implemented.

The researcher used secondary sources of data for analysis. The coverage of data for this particular study encompassed the year 2018 for the top 10 and lowers 10 LPI scorer countries. In order to collect the data, the researchers used the official Websites of the World Bank and associated organizations. Additional information also collected from different sources includes the international organizations' policy and standards documents and international organizations' annual 
reports like the World Trade Organization (WTO), Organization for Economic Cooperation and Development (OECD), United Nations Conference on Trade and Development (UNCTAD), organizations' internal reports, publications, newspapers, journals, documents from respective government offices, etc.

Better logistics service is indispensable to integrate global value chains and reap the benefit of trade opportunities for sustainable growth and poverty reduction. The ability to connect to the global logistics web depends on a country's distance from a partner country, infrastructure, service markets, and trade processes. Government and the private sector in many developing countries should improve these areas or face the large and growing costs of exclusion. According to the World Bank report (2016), there are 160 countries worldwide that recorded their LPI and GCI within two years interval, out of which, the top first ten, and lower ten countries were selected purposively to evaluate their competitiveness.

After data has been collected, data processing was carried out. The raw data converted into a suitable form for analysis and interpretation. This has been achieved through sequences of activities including coding, entry, and tabulation. The objective has to check the completeness, internal consistency, and appropriateness of the data to each of the variables. Statistical analysis was carried out by using Excel and Statistical Package for Social Science (SPSS) Software (V.24).

Descriptive statistics were employed to give a deeper analysis of data. Moreover, GCI and LPI indexes had used to select the top and bottom 10 ranked countries. Inferential statistics like the gravity model were also applied to identify the effect of freight transport service on international trade competitiveness. Furthermore, the extent of international trade competitiveness and its implications in the global market is assessed by the bilateral trade error series.

The expected econometrics gravity model with the given attritions as per the conceptual model illustrated as follow:

$$
\begin{aligned}
& \ln \left(\delta_{i j}\right)=\alpha+\beta_{i} \ln (G D P)_{j}+\tau_{1} \ln \left(\text { Dis }_{i j} \tan c e\right)+\tau_{2} \text { Landlocked }_{i}+\tau_{3} \ln \left(\text { Time }_{i j}\right)+\tau \\
& \text {... (Equation: } 1)
\end{aligned}
$$

Where:

$\delta_{i j}$ : is measured as exports from country $\mathrm{i}$ to country $\mathrm{j}$

$\beta_{1} G D P_{j}$ : Gross Domestic products of country $\mathrm{j}$.

$\tau_{i}$ : can be interpreted as the elasticity of trade concerning distance (It is a bilateral variable).

$\mathrm{i}=1,2, \ldots, 4$

Landlocked $_{i}$ : Dummy variable

Timeline: The time (frequency) to accomplish exports of country $i$ and imports of country $j$, process or the time (frequency) where exports of country $i$ and imports of country $j$ to complete route the scheduled expected time.

Infrastructor : The quality of trade and transport-related infrastructure to export from country $\mathrm{i}$ to import country $\mathrm{j}$.

$v_{i j}$ : Error terms of exports of country i and imports of country $\mathrm{j}$.

\section{Data Analysis, Presentation, and Interpretation of the Findings}

\subsection{Effect of Freight Transport on International Trade Competitiveness In terms of the top 10 best LPI scorers country}

The gravity model is widely implemented to evaluate the effect of logistic performance on trade competitiveness. Moreover, it is also used to analyze the trade pattern, estimate the marginal cost of 
trade barriers, and explain the economic phenomena in reality. Hence, the gravity model is applied to measure trade in services international competition as a new index. Taking this consideration into account, and due to the consideration of the model indicated in equation (1), the study used to analyze the data to determine the effect of logistics performance on the bilateral trade flows of selected countries. To do so, the study takes the top 10 highest LPI scorer countries on one hand and the bottom 10 lower LPI scorers during 2018 on the other hand. The gravity model was built based on the major effect of logistics such as GDP, timeline, the distance between bilateral countries, infrastructure, and landlocked on the total trade.

The log-linear regression, gravity, model as indicated in equation (1) was conducted to examine the causal and strengthens of a relationship between the exporter trades with partner countries of the world. In the model, the parameters were estimated using the Ordinary Least Squares (OLS) method, and for the selection of the regression, variables were used the stepwise method. The basic idea of stepwise regression is "Inclusion or Exclusion". That is the approach used to select variables one by one based on some of the squares of argument regression. Involve arguments one by one in the regression model and test them for statistical significance, delete any that are not significant. Methods are a combination of the above, testing at each stage for variables to be included or excluded.

The ANOVA test helps to determine whether the formulated model is significant (Sig. <0.05) variation in bilateral trade flows, based on factors included in the model or not. As the result illustrated in the table below, the F-test of the entered countries' p-values were below the significant threshold (0.05); so, there is evidence that the model is fitted or good for the given purpose. But, the inclusion determinant factors differ one from the others, for instance, the German trade was found with the lowest residual error in the fourth model (Regression $\mathrm{df}=4$ ), Netherland in the third (Regression $\mathrm{df}=3$ ), Belgium in the third (Regression $\mathrm{df}=3$ ), etc.

Table 1. Model specification (ANOVA)

\begin{tabular}{|c|c|c|c|c|c|c|}
\hline Countries & Model & SSS & df & MS & $\mathbf{F}$ & Sig. \\
\hline & Regression & 23.432 & 4 & 5.858 & 16.894 & 0.000 \\
\hline \multirow[t]{3}{*}{ German } & Residual & 11.789 & 34 & 0.347 & & \\
\hline & Total & 35.221 & 38 & & & \\
\hline & Regression & 27.340 & 3 & 9.113 & 16.480 & 0.000 \\
\hline \multirow[t]{2}{*}{ Netherland } & Residual & 21.566 & 39 & 0.553 & & \\
\hline & Total & 48.906 & 42 & & & \\
\hline \multirow[t]{3}{*}{ Belgium } & Regression & 47.374 & 3 & 15.791 & 35.639 & 0.000 \\
\hline & Residual & 16.838 & 38 & 0.443 & & \\
\hline & Total & 64.212 & 41 & & & \\
\hline \multirow[t]{3}{*}{ UK } & Regression & 60.270 & 2 & 30.135 & 41.596 & 0.000 \\
\hline & Residual & 30.428 & 42 & 0.724 & & \\
\hline & Total & 90.697 & 44 & & & \\
\hline \multirow[t]{3}{*}{ Singapore } & Regression & 9.666 & 1 & 9.666 & 4.469 & 0.040 \\
\hline & Residual & 90.836 & 42 & 2.163 & & \\
\hline & Total & 100.502 & 43 & & & \\
\hline \multirow[t]{3}{*}{ Sweden } & Regression & 7.921 & 1 & 7.921 & 8.712 & 0.006 \\
\hline & Residual & 30.005 & 33 & 0.909 & & \\
\hline & Total & 37.927 & 34 & & & \\
\hline \multirow[t]{3}{*}{ Norway } & Regression & 44.321 & 3 & 14.774 & 15.469 & 0.000 \\
\hline & Residual & 35.338 & 37 & 0.955 & & \\
\hline & Total & 79.659 & 40 & & & \\
\hline \multirow[t]{3}{*}{ Luxembourg } & Regression & 28.338 & 2 & 14.169 & 11.842 & 0.000 \\
\hline & Residual & 49.058 & 41 & 1.197 & & \\
\hline & Total & 77.396 & 43 & & & \\
\hline \multirow[t]{3}{*}{ US } & Regression & 18.770 & 1 & 18.770 & 25.219 & 0.000 \\
\hline & Residual & 29.771 & 40 & 0.744 & & \\
\hline & Total & 48.541 & 41 & & & \\
\hline \multirow[t]{3}{*}{ Japan } & Regression & 19.598 & 2 & 9.799 & 9.859 & 0.000 \\
\hline & Residual & 36.776 & 37 & 0.994 & & \\
\hline & Total & 56.374 & 39 & & & \\
\hline
\end{tabular}


Having the above concept in mind, the next question which follows would be how good the model is. The answer is given by the goodness of fit test $\left(\mathrm{R}^{2}\right)$ value. That is, the value of $\mathrm{R}$ square is used to measure how much of the variation in the dependent variable, bilateral trade flow, is identified by the regressors. The larger the value of $\mathrm{R}$ square, the better it fits. Table 2 illustrated $\mathrm{R}, \mathrm{R}$ square, adjusted $\mathrm{R}$ square, and the standard error of the estimate. $\mathrm{R}$ is the multi-correlation coefficient which measures the relationship between the dependent and predictor variables. The values of $\mathrm{R}$ range from -1 to 1 . The sign of $R$ indicates the direction of the relationship (positive or negative). The absolute value of $R$ indicates the strength, with larger absolute values indicating a stronger linear relationship.

The coefficient ( $\mathrm{R}$ square) helps to quantify the proportion of variation in the dependent variable explained by the regression model. It is ranges from 0 to 1 . Small values indicate that the explainable level of the independent variables to determine the dependent variable is weak. The sample $\mathrm{R}$ squared tends to optimistically estimate how well the models fit for the population. Both R squared and adjusted $\mathrm{R}$ square somehow has the same meaning and purpose. But, adjusted $\mathrm{R}$ square is applicable for the small numbers of observations $(\mathrm{n}<30)$ or numbers of variables (No. of variable <5) (Julie, 2011). So, in the case of this study, the researcher used R square, because the size of the data seat, as well as the number of variables full, failed the above criteria.

Therefore, as shown in the table below the $\mathrm{R}$ square results lay between 0.096 and 0.738 . For example, the R square of Belgium's bilateral trade flows with the models based on all the regression factors is 0.738 . This means the chosen model explains $73.8 \%$ of the variation of the dependent variable, the bilateral trade flow between Belgium and partner countries. Likewise, the bilateral trade flow between partner countries and Germany is $66.5 \%$, UK $66.5 \%$, Netherland $55.9 \%$, and Norway $55.6 \%$ of the variation covered by the inclusive factors in the fitted model; whereas, the R square values of Singapore bilateral trade flow with other partners is 0.096 , i.e., $9.6 \%$ of the variation of the dependent variable explained by the considered factors in the fitted model. The below table illustrates more about the goodness of fit test of the model that is considered by all the conserved countries (Table 2).

Table 2. Goodness of fit test

\begin{tabular}{lllll}
\hline Country & R & R square & Adj. R Square & Std. error of the estimate \\
\hline Germen & 0.816 & 0.665 & 0.626 & 0.5885 \\
Netherland & 0.748 & 0.559 & 0.525 & 0.7436 \\
Belgium & 0.859 & 0.738 & 0.717 & 0.3354 \\
UK & 0.815 & 0.665 & 0.649 & 0.8512 \\
Singapore & 0.310 & 0.096 & 0.075 & 1.4706 \\
Sweden & 0.457 & 0.209 & 0.185 & 0.9536 \\
Norway & 0.746 & 0.556 & 0.520 & 0.9773 \\
Luxembourg & 0.605 & 0.366 & 0.335 & 1.0939 \\
US & 0.622 & 0.387 & 0.371 & 0.8627 \\
Japan & 0.590 & 0.348 & 0.312 & 0.9970
\end{tabular}

The result of the regression analysis presented in the table below also provides a more comprehensive and accurate examination of the research questions. Therefore, the regression analysis is used to test the developed questions based on the specific objectives and investigate the contributions of the independent variables over the dependent ones.

\section{German}

The variables which influence Germen's bilateral trade were: the distance between German and partner countries, GDP of the partner countries, a timeline, and landlocked. However, infrastructure did not influence bilateral trade because the factor is insignificant.

According to the study finding, Germany tends to have trade relations with countries where their total GDP is higher. The estimated coefficient of this variable has statistical significance and shows 
positive influences, in line with expectations when constructing the model. After taking the remaining effect as a constant, a 1\% increment of partners' GDP would lead to enhancing trade value by approximately $0.572 \%$. In other terms, Germany has more intense external trade with countries that have a better GDP than with countries with lower GDP.

Geographical distance is statistically significant and estimated to impair bilateral trade between Germany and its partners. That is, with an increase of $1 \%$ of the distance, the trade value would decrease by $1.165 \%$ on average. So, the negative correlation between bilateral trade flow and the geographical distance shows that the greater the distance between Germany and the partner country, the lower is the trade volume between the two.

The study finding also indicated that the timeline of reaching and loading off had a positive impact on trade flows between Germany and trade partners. This means when the timeline between Germany and partners improved the trade relation also went with the same line. For instance, if the timeline improved by $1 \%$ after taking the other effect as a constant the trade flow of Germany would be elongated by $3.037 \%$. This implies Germany has a better relationship with the countries which have good time management. Besides, landlocked has a significant effect on the bilateral trade of Germany and its partners. Accordingly, the bilateral trade flow and landlocked show that Germany has more intensified trade activities with countries that had a port than landlocked countries.

\section{Netherland}

Timeline, GDP, and distance are significantly important factors to determine the bilateral trade flow of the Netherlands. That is, this country's trade flow would escalate if the duration of trade distribution improves. After controlling the remaining effect as a constant, for a $1 \%$ change in the timeline, the bilateral trade flow of the Netherlands with its partners would lead to an increase of $3.707 \%$ times.

The Netherlands has more intense external trade with countries that have higher GDP than with countries with lower GDP. For a $1 \%$ increment of partners, GDP would enlarge a $32.8 \%$ increment of trade flow of the Netherlands. Contrarily, the geographical distance has an inverse association with the trade flow. This implies, for a $1 \%$ increment of distance, the trade value would lead to a decline of $0.291 \%$. In other words, the greater the distance between the Netherlands and the partner country, the lower is the trade volume between the two.

\section{Belgium}

The bilateral trade flow of Belgium and its partners depending on GDP, distance, and infrastructure. For instance, a $1 \%$ increase in GDP, would lead to escalating $0.64 \%$ of the trade value. This implies Belgium has more intense external trade with countries that have higher GDP. Likewise, as the result illustrates, if the infrastructure of the partner country increases by $1 \%$, the bilateral trade value of Belgium would step up by roughly $1.956 \%$. That is Belgium is mostly attracted by the infrastructure development of the partner countries for the bilateral trade flows. However, distance is negatively affecting the bilateral trade flow of Belgium and its partners. In that regard, a $1 \%$ increment of geographical distance would lead to a decrease of $0.528 \%$ of the trade value. In other words the greater the distance between Belgium and the partner country, the lower is the trade volume within them.

\section{UK}

Infrastructure and GDPs are highly statistically significant to determine the bilateral trade between the UK and its partner's countries on the trade flow. If the infrastructure of the partner countries increases by $1 \%$, the bilateral trade value of the UK would intensify by roughly $3.617 \%$. That is the UK has more strengthened trade activities with countries that had better infrastructure facilitation, compared to countries with low infrastructure. Moreover, the GDP is significantly important to determine the bilateral trade flow of the UK and its partners, i.e., the UK has more strengthened trade activities with countries that had more GDP, compared to countries with low growth domestic products. 


\section{Singapore}

Singapore's trade flow was highly dominated only by geographical distance. Hint, geographical distance is statistically significant and estimated to impair bilateral trade between Singapore and its trade partners. That is, for a unit person increment of distance would lead to a decrease in the bilateral trade of Singapore by $0.438 \%$. It indicates when the country's distance with its partner is wider; the possibility of reaching it would be declined.

\section{Sweden}

Like Singapore, Sweden's trade flow with partners would under consider the geographical distance only. As the study finding illustrated, the bilateral trade flow and the geographical distance developed a negative association. So, the greater the distance between Sweden and the partner country, the lower is the trade volume between them.

\section{Norway}

Norway's bilateral trade flow was also determined by infrastructure, GDP, and the distance between the country and its partners. The infrastructure status of the partner countries plays a significant role in the Norway trade flow choice. Accordingly, if the infrastructures of the partner countries increased by $1 \%$ the Norway trade flow choice would also be elongated by $3.248 \%$. That is, Norway has a bigger trade volume with countries having better infrastructure. Likewise, the GDP of the partner countries plays a significant role to work with Norway. This means when the growth of the domestic product of the partners' country escalates by $1 \%$ Norway's intense trade relationship with them would escalate by $0.199 \%$. In other words, Norway has powerful external trade with countries that have a higher GDP than with the lowest.

Regarding the geographical distance, it impairs bilateral trade between Norway and partners indicating inverse association. If the partner countries' distance increased by $1 \%$, the trade value of Norway decreased by $0.352 \%$ after taking the other effect as a constant. This means, the greater the distance between Norway and the partner country, the lower is the trade volume between the two.

\section{Luxembourg}

Timeline and GDP are statistically significant and estimated to impair bilateral trade between Luxembourg and its trade partners. Both of the determinant factors have a positive association; i.e., the increment of them leads to an increase in their trade association. For instance, if the timeline of the partners' country improved by $1 \%$, correspondingly Luxembourg's trade volume would rise by $5.146 \%$. In other terms, Luxembourg has made stronger trade activities with countries that have better port time management, compared to countries with a lower timeline. Similarly, Luxembourg's trade was also influenced by its partners' GDP. GDP is statistically significant with a positive impact. So, if the GDP of the partner country increases by $1 \%$, the bilateral trade flow of Luxembourg would step up by $0.204 \%$. That is, Luxembourg has more intense external trade with countries that have higher GDP than with the countries with lower GDP.

\section{US}

GDP was the only influential factor for the trade flow activities of the US. The bilateral trade between the US and partners was linked with the consideration of better GDP. That is, the GDP of the partner countries elongated by $1 \%$, the trade value of the US would escalate up by $0.521 \%$. In other words, the US has powerful external trade with countries that have better GDP. 


\section{Japan}

The study finding also illustrated in the table below that the bilateral trade flow of Japan was explained by infrastructure and the distance between the partner countries. Infrastructure had a positive effect on trade flow. The infrastructure status of partner countries increases by $1 \%$, the trade value would escalate by $29.724 \%$. That is, Japan has more intense external trade with countries that have better infrastructure. Moreover, geographical distance is statistically significant and important to impair bilateral trade between Japan and its partners. This impels, if the distance increases by $1 \%$, the trade flow of Japan would decrease by $1.165 \%$. The negative correlation between bilateral trade flow and the geographical distance indicated that the greater the distance between Japan and the partner country, the lower is the trade volume between them.

Table 3. Estimate of trade flow between the given countries with their partners

\begin{tabular}{|c|c|c|c|c|c|c|}
\hline \multirow[b]{2}{*}{ Countries } & \multirow[b]{2}{*}{ Model } & \multicolumn{2}{|c|}{ Unstandardized coefficient } & \multicolumn{3}{|l|}{ Standardized coefficient } \\
\hline & & B & Std. Error & Beta & $\mathbf{t}$ & Sig. \\
\hline & Constant & 18.594 & 1.742 & & 10.672 & 0.000 \\
\hline \multirow[t]{5}{*}{ German } & Distance & -0.353 & 0.088 & -0.438 & -4.033 & 0.000 \\
\hline & GDP & 0.572 & 0.081 & 0.822 & 7.105 & 0.000 \\
\hline & Time line & 3.037 & 1.117 & 0.279 & 2.719 & 0.010 \\
\hline & Land locked & 0.811 & 0.345 & 0.259 & 2.347 & 0.025 \\
\hline & Constant & 17.42 & 1.992 & & 8.744 & 0.000 \\
\hline \multirow[t]{4}{*}{ Netherland } & Time line & 3.707 & 1.264 & 0.339 & 2.932 & 0.006 \\
\hline & GDP & 0.328 & 0.074 & 0.500 & 4.414 & 0.000 \\
\hline & Distance & -0.291 & 0.099 & -0.336 & -2.937 & 0.006 \\
\hline & Constant & 19.584 & 1.012 & & 19.334 & 0.000 \\
\hline \multirow[t]{4}{*}{ Belgium } & GDP & 0.640 & 0.096 & 0.643 & 6.631 & 0.000 \\
\hline & Distance & -0.528 & 0.085 & -0.552 & -6.242 & 0.000 \\
\hline & Infrastructure & 1.956 & 0.679 & 0.267 & 2.880 & 0.007 \\
\hline & Constant & 14.563 & 0.832 & & 17.502 & 0.000 \\
\hline \multirow[t]{3}{*}{ UK } & Infrastructure & 3.617 & 0.774 & 0.489 & 4.671 & 0.000 \\
\hline & GDP & 0.427 & 0.100 & 0.445 & 4.255 & 0.000 \\
\hline & Constant & 25.506 & 1.809 & & 14.097 & 0.000 \\
\hline \multirow[t]{2}{*}{ Singapore } & Distance & -0.438 & 0.207 & -0.610 & -2.114 & 0.040 \\
\hline & Constant & 14.847 & 2.269 & & 6.545 & 0.000 \\
\hline \multirow[t]{2}{*}{ Sweden } & Distance & 4.899 & 1.660 & 0.457 & 2.952 & 0.006 \\
\hline & Constant & 17.962 & 1.451 & & 12.379 & 0.000 \\
\hline \multirow[t]{3}{*}{ Norway } & Infrastructure & 3.248 & 0.898 & 0.441 & 3.616 & 0.001 \\
\hline & Distance & -0.352 & 0.117 & -0.331 & -3.006 & 0.005 \\
\hline & GDP & 0.199 & 0.080 & 0.302 & 2.483 & 0.018 \\
\hline \multirow[t]{4}{*}{ Luxembourg } & Constant & 10.140 & 1.967 & & 5.155 & 0.000 \\
\hline & Time & 5.146 & 1.538 & 0.439 & 3.347 & 0.002 \\
\hline & GDP & 0.204 & 0.089 & 0.299 & 2.282 & 0.028 \\
\hline & Constant & 20.196 & 0.678 & & 29.796 & 0.000 \\
\hline \multirow[t]{2}{*}{ US } & GDP & 0.521 & 0.104 & 0.622 & 5.022 & 0.000 \\
\hline & Constant & 29.724 & 2.828 & & 10.511 & 0.000 \\
\hline \multirow[t]{2}{*}{ Japan } & Distance & -1.165 & 0.288 & -0.540 & -4.047 & 0.000 \\
\hline & Infrastructure & 2.588 & 1.165 & 0.297 & 2.222 & 0.032 \\
\hline
\end{tabular}

\section{The Bottom Ten Lower LPI Ranked Countries}

In this portion, the study took the bottom lower LPI scorers countries for examination. Here the regression estimation is also carried out based on the model specification. The result shows how the explanatory variables affect the bilateral trade flows of the countries. Even if the independent variables, geographical distance, GDP, timeline, infrastructure, and landlocked, are considered in the evaluation, due to poor computability of these countries some of them like Guili, Burundi, Afghanistan, Senegal, Myanmar, and Mauritania, the effect could not fit with the dependent variable, bilateral trade. In other words, because these explanatory variables were shielded with great variability, they couldn't show their effect on the bilateral trade. Even the poor model formulated by using the data would be supposed to lead to a wrong conclusion. Therefore, the researcher has to restrict some lowest LPI countries to those capable of fully file the model specification. 
The analysis of the data presented in Table 4, ANOVA results, indicated that the models explained significant variation in bilateral trade flows, based on factors included in the model (Sig.

$<0.05$ ). That is, the model indicated the lowest residual error, the one that, consequently, has the highest goodness of fit value. On the other hand, the F test is highly statistically significant, which means the regression model is fitted to the data. Thus, the study explanatory variables statistically significantly predict the flow of trade from country $i$ to $j$.

As the findings of the study illustrated Fiji, Madagascar, and Sierra Leone bilateral trade is included in the first stage model ( $\mathrm{df}=1)$, whereas, Bolivia includes the second stage model $(\mathrm{df}=2)$ with minimal error. The F-test of the p-value was found between 0.001 and 0.017 and the significant value is 0.05 . Hence, the significance (sig.) value is greater than that of the p-value; therefore, the models representing the bilateral trade of the indicated countries are fitted.

Table 4. Model specification (ANOVA)

\begin{tabular}{|c|c|c|c|c|c|c|}
\hline Countries & Model & SSS & df & MS & $\mathbf{F}$ & Sig. \\
\hline & Regression & 75.555 & 1 & 75.555 & 6.292 & 0.017 \\
\hline \multirow[t]{3}{*}{ Fiji } & Residual & 384.236 & 32 & 12.007 & & \\
\hline & Total & 459.791 & 33 & & & \\
\hline & Regression & 102.880 & 2 & 51.440 & 5.952 & 0.007 \\
\hline \multirow[t]{3}{*}{ Bolivia } & Residual & 241.979 & 28 & 8.642 & & \\
\hline & Total & 344.859 & 30 & & & \\
\hline & Regression & 104.727 & 1 & 104.727 & 12.617 & 0.001 \\
\hline \multirow[t]{2}{*}{ Madagascar } & Residual & 215.814 & 26 & 8.301 & & \\
\hline & Total & 320.541 & 27 & & & \\
\hline \multirow[t]{3}{*}{ Sierra Leone } & Regression & 68.819 & 1 & 68.819 & 6.557 & 0.014 \\
\hline & Residual & 461.805 & 44 & 10.496 & & \\
\hline & Total & 530.624 & 45 & & & \\
\hline
\end{tabular}

The goodness of fit test of gravity model estimation result, which is indicated in the table below, illustrated that the R-square of Fiji, 0.164; i.e., the issued explanatory variable/s $16.4 \%$ explains the bilateral trade volume. Likewise, Madagascar's bilateral trade flow was explained $32.7 \%$ by the included factor. Comparably, the Sierra Leone goodness of fit test is lesser than that of Bolivia's model to explain trade flows of the lower LPI countries to the global market. This indicates the issued independent variable/s ability to explain the trade flow of Bolivia is a bit better than Sierra Leone's. In general, the largest $\mathrm{R}$ square indicates the better the fit is (Table 4.18).

Table 5. Goodness of fit test

\begin{tabular}{lllll}
\hline Country & R & R square & Adj. R Square & Std. error of the estimate \\
\hline Fiji & 0.405 & 0.164 & 0.138 & 3.46517 \\
Bolivia & 0.546 & 0.298 & 0.248 & 2.93974 \\
Madagascar & 0.572 & 0.327 & 0.301 & 2.88107 \\
Sierra Leone & 0.360 & 0.130 & 0.110 & 3.23969
\end{tabular}

The regression model indicated in the below table shows every of the listed countries' estimates for the dependent variables which are the export value (Trade) and effect of logistic performance include bilateral distance, exporter GDP, infrastructure, timeline, and landlocked. The individual inclusive countries details are shown as follow:

\section{Fiji}

Evidence on the effect of trade logistics performance on Fiji trade has been secured, under the dimension of GDP. Having this, estimation has made for each of the LPI components based on the research equations. The study explanatory variables coefficients with their significance level have summarized in the table below.

According to the study findings GDP of the importer, countries have statistically significant positive effects on bilateral trade flows, with the coefficient 0.774 . This indicates for a $1 \%$ increment 
in GDP would tend to upsurge the bilateral trade of Fiji by $0.774 \%$. This establishes Fiji has more intense external trade with countries that have higher GDP than with the countries with lower GDP.

\section{Bolivia}

In studying the effect of the bilateral trade flow of Bolivia, variables such as GDP and geographical distance are statistically significant with a 0.05 level of significance. In terms of economic size, GDP has a significant positive effect on the bilateral trade flows of Bolivia. As the result revealed, a $1 \%$ increase in GDP will tend to increase export value by $0.780 \%$ after controlling the remaining effect as a constant. Likewise, geographical distance negatively impacted the bilateral trade flows of Bolivia. However, the two variables are associated inversely once with the other. This means, after controlling the other effect as a constant for a $1 \%$ increase in bilateral distance between Bolivia and partners, it will tend to reduce the bilateral trade by $1.034 \%$. This implies countries with a long geographical distance from Bolivia would have low trade interaction.

\section{Madagascar}

Madagascar's trade is affected by the infrastructure development of the partner countries. This fracture is statistically significant with a positive impact. So, if the infrastructure of the partners' country increases by $1 \%$, the bilateral trade value of Madagascar would step up by roughly $7.505 \%$. This implies Madagascar has a bigger trade volume with countries having better logistic infrastructure development.

\section{Sierra Leone}

The study findings also confirmed that GDP is statistically significant and estimated to impair bilateral trade between Sierra Lion and its trade partners. That is when the GDP of the partner countries increases by $1 \%$ bilateral trade of Sierra Lion would also increase by $0.518 \%$. This implies Sierra Lion would share trade mostly with countries with bigger economic sizes.

Table 6. Estimate of trade flow between the given countries with their partners

\begin{tabular}{|c|c|c|c|c|c|c|}
\hline \multirow[b]{2}{*}{ Countries } & \multirow[b]{2}{*}{ Model } & \multicolumn{2}{|c|}{ Unstandardized coefficient } & \multirow{2}{*}{$\begin{array}{c}\text { Standardized coefficient } \\
\text { Beta }\end{array}$} & \multirow[b]{2}{*}{$\mathbf{T}$} & \multirow[b]{2}{*}{ Sig. } \\
\hline & & B & Std. Error & & & \\
\hline & Constant & 1.818 & 1.898 & & 0.958 & 0.345 \\
\hline \multirow[t]{2}{*}{ Fiji } & GDP & 0.774 & 0.308 & 0.405 & 2.508 & 0.017 \\
\hline & Constant & 12.120 & 4.697 & & 2.581 & 0.015 \\
\hline \multirow[t]{3}{*}{ Bolivia } & GDP & 0.780 & 0.263 & 0.473 & 2.970 & 0.006 \\
\hline & Distance & -1.034 & 0.497 & -0.331 & -2.079 & 0.047 \\
\hline & Constant & -1.407 & 2.510 & & -0.561 & 0.580 \\
\hline \multirow[t]{2}{*}{ Madagascar } & Infrastructure & 7.505 & 2.113 & 0.572 & 3.552 & 0.001 \\
\hline & Constant & 8.755 & 1.249 & & 7.012 & 0.000 \\
\hline Sierra Leone & GDP & 0.518 & 0.202 & 0.360 & 2.561 & 0.014 \\
\hline
\end{tabular}

\subsection{Measurement of International Competitiveness of Trade Services}

Different indexing systems help to test international trade competitiveness. Commonly, reviewing the studies of trade competition, three indexes are usually applied. One is Revealed Comparative Advantage Indices (RCA), the other is Trade Special Coefficient (TSC) and the third one is the bilateral trade error series. In this study, the researcher used the bilateral trade error series.

To determine the degree of trade efficiency or inefficiency, the researcher calculated, for the error series, the one standard deviation interval around the mean, which is $(-1,+1)$. If the error values are outside the range, then for positive values there is a high efficiency of bilateral trade; whereas, for negative values, there is a highly inefficient trade (Elena-Daniela, 2012).

To analyze the efficiency of the listed top 10 and bottom 4 LPI scorer countries' bilateral trade with their partner countries, as the literature suggested above the researcher has analyzed the model error series that resulted from estimating the competitiveness of bilateral trade. Accordingly, negative error values indicate that the real value of the bilateral trade flow is below the estimated one; whilst, 
positive error values indicate the real value is greater than the estimated value. The working hypothesis is that negative error values indicate an inefficient trade or uncompetitive, which has not reached its potential; but, a positive error value shows an effective trade or competitive, above the theoretical potential.

Taking the above consideration into account, this study examined and executed, from the individual top as well as bottom LPI scorer countries, few beasts competitive and few uncompetitive trade partners and list in the table below.

As the study revealed in the table below most of the selected countries developed various kinds of trade associations with their partners. The researcher specified the partners' country as per their level of efficient trade assistance with the domain country. For example, regarding the area, Germany had the most efficient bilateral trade with the EU and Asian countries. Some of the European partners deployed ineffective trade relations with Germany, for instance, Luxembourg had a very inefficient trade relation; so, their trade association was not competitive.

Likewise, the Netherlands, Belgium, and the UK had the most efficient bilateral trade with the EU countries. However, Singapore and Sweden had the best trade link with Middle Asia and African countries. Moreover, Norway, Luxembourg, and the U.S had the highest trade link with EU, Asian, and Southern American countries. In contrast, Sweden and Luxembourg are the most ineffective trade partnerships with the Netherlands. Latvia and Japan have also had a very weak trade link with Belgium. Most of the African countries except Nigeria and South Africa did not have any trade link with the most top LPI scorer countries. Even South Africa had an inefficient trade link with Sweden. Amicably, Nigeria had a highly efficient bilateral trade link with Belgium. As the above topics illustrated most of the highest LPI scorer countries in 2018 were European countries. According to this study finding those countries usually had an effective market link with themselves as well as Asian countries mostly. These indicated that the countries mostly competent and better trade links with themselves or with the inpouring continents. The below table illustrated more about the global trade link effectiveness of higher LPI scorer countries (Table 7).

The most bottom LPI scorer countries also have an effective or ineffective trade link with their partner countries. For instance, Fiji had the most effective trade partner link with Canada, Dominica, China, and India. Likewise, Bolivia's most effective partnerships were Australia and Cyprus; whereas, it has a highly ineffective trade link with Spain and India. Moreover, Madagascar had the most efficient bilateral trade with EU countries like Chile and the UK. But, Sierra Leone had good trade links with African countries. Even if these lower LPI scorer countries had effective trade links with some partners, it was not effective enough for their growth. In addition to that most of their partners were from developing nations like Asia, South America, and Africa (Table 8). 
Table 7. Some trade competent partners of high LPI scorer countries

\begin{tabular}{|c|c|c|c|c|c|}
\hline \multicolumn{2}{|r|}{ German } & \multicolumn{2}{|r|}{ Netherland } & \multicolumn{2}{|r|}{ Belgium } \\
\hline Countries & Competitiveness & Countries & Competitiveness & Countries & Competitiveness \\
\hline Luxembourg & Highly incompetent & Sweden & Highly incompetent & Latvia & Highly incompetent \\
\hline Japan & Incompetent & Luxembourg & Highly incompetent & Japan & Highly incompetent \\
\hline Norway & Incompetent & Thailand & Incompetent & Norway & Incompetent \\
\hline Canada & Incompetent & Japan & Incompetent & Mexico & Incompetent \\
\hline Hungary & Competent & Mexico & Incompetent & Austria & Incompetent \\
\hline South Korea & Competent & Turkey & Competent & Poland & Competent \\
\hline Slovakia & Competent & Czech Republic & Competent & India & Competent \\
\hline Czech Republic & Competent & Hungary & Competent & U.A.E & Competent \\
\hline Island & Highly competent & Belgium & Highly competent & Nigeria & Highly competent \\
\hline Australia & Highly competent & Germany & Highly competent & Germany & Highly competent \\
\hline & UK & & ingapore & & Sweden \\
\hline Taiwan & Highly incompetent & Pakis & Highly incompetent & Ireland & Highly incompetent \\
\hline Austria & Highly incompetent & Italy & Highly incompetent & Hungary & Highly incompetent \\
\hline Check Republic & Incompetent & Bahamas & Incompetent & South Africa & Incompetent \\
\hline Finland & Incompetent & Canada & Incompetent & Austria & Incompetent \\
\hline Slovakia & Incompetent & Spain & Incompetent & Czech & Incompetent \\
\hline Germany & Competent & Philippines & Competent & Russia & Competent \\
\hline Netherland & Competent & Belgium & Competent & Netherland & Competent \\
\hline Belgium & Competent & German & Competent & UK & Competent \\
\hline Switzerland & Highly competent & Thailand & Highly competent & Finland & Highly competent \\
\hline Island & $\begin{array}{l}\text { Highly competent } \\
\text { Norway }\end{array}$ & Vietnam & Highly competent & $\begin{array}{l}\text { China } \\
\text { US }\end{array}$ & Highly competent \\
\hline Israel & Highly incompetent & $\begin{array}{l}\text { Luxembourg } \\
\text { Japan }\end{array}$ & Highly incompetent & Qatar & Highly incompetent \\
\hline Austria & Highly incompetent & Israel & Highly incompetent & Egypt & Highly incompetent \\
\hline Spain & Incompetent & Finland & Incompetent & Norway & Incompetent \\
\hline Singapore & Incompetent & Lithuania & Incompetent & South & Incompetent \\
\hline Oman & Incompetent & India & Incompetent & New Zealand & Incompetent \\
\hline Portugal & Competent & Austria & Competent & Nether & Competent \\
\hline Denmark & Competent & UK & Competent & Guatemala & Competent \\
\hline Poland & Competent & Switzerland & Competent & Singapore & Competent \\
\hline US & Highly competent & Russia & Highly competent & Honk Kong & Highly competent \\
\hline Belgium & $\begin{array}{l}\text { Highly competent } \\
\text { Japan }\end{array}$ & Italy & Highly competent & Columbia & Highly competent \\
\hline Hungary & Highly incompetent & & & & \\
\hline South Africa & Highly incompetent & & & & \\
\hline New Zealand & Incompetent & & & & \\
\hline Kuwait & Incompetent & & & & \\
\hline Israel & Incompetent & & & & \\
\hline Singapore & Competent & & & & \\
\hline India & Competent & & & & \\
\hline Malaysia & Competent & & & & \\
\hline Mexico & Competent & & & & \\
\hline Canada & Competent & & & & \\
\hline
\end{tabular}


Table 8. Some trade competent partners of low LPI scorer countries

\begin{tabular}{|c|c|c|c|c|c|}
\hline \multicolumn{2}{|c|}{ Fiji } & \multicolumn{2}{|c|}{ Bolivia } & \multicolumn{2}{|c|}{ Madagascar } \\
\hline Countries & Competitiveness & Countries & Competitiveness & Countries & Competitiveness \\
\hline Czech Republic & Highly incompetent & Spain & Highly incompetent & Australia & Highly incompetent \\
\hline Belgium & Highly incompetent & India & Highly incompetent & Argentina & Highly incompetent \\
\hline Argentina & Incompetent & Liberia & Incompetent & Brazil & Incompetent \\
\hline Chile & Incompetent & Israel & Incompetent & Finland & Incompetent \\
\hline Iraq & Incompetent & Argentina & Incompetent & Bahrain & Incompetent \\
\hline France & Competent & China & Competent & Egypt & Competent \\
\hline Canada & Highly competent & Ireland & Competent & Eritrea & Competent \\
\hline Dominica & Highly competent & Italy & Competent & Burkina & Competent \\
\hline China & Highly competent & Austria & Highly competent & Chile & Highly competent \\
\hline \multirow[t]{2}{*}{ India } & Highly competent & Cyprus & Highly competent & UK & Highly competent \\
\hline & Leone & & & & \\
\hline Germany & & $\begin{array}{l}\text { Highly } \\
\text { incompetent }\end{array}$ & & & \\
\hline Seychell & & $\begin{array}{l}\text { Highly } \\
\text { incompetent }\end{array}$ & & & \\
\hline Turkey & & Incompetent & & & \\
\hline Kenya & & Incompetent & & & \\
\hline Indonesia & & Incompetent & & & \\
\hline Vietnam & & Competent & & & \\
\hline Bangladesh & & Competent & & & \\
\hline Spain & & Competent & & & \\
\hline The Gambia & & Highly competent & & & \\
\hline South Africa & & Highly competent & & & \\
\hline
\end{tabular}

\section{Conclusion}

The results of this study give a better understanding of the logistic effect on global trade competitiveness. Freight transport service and international trade are some of the most expedient economic factors in pushing economies to transition and integration. The general trend in the development of international trade has been influenced by the logistics effect such as GDP, distance, infrastructure, timelines, and landlocked. Researchers have sought both to compute the relationships of freight transport service and international trade with its implication on global competitiveness through how they operate and explore the returns.

Most of the countries' trades depend on the size of the economies (GDP), Infrastructure, landlocked, and timelines. But, the geographical distance between bilateral countries also has a significant negative impact on a country's trade. Therefore, to trade competently with the highest LPI scorer countries, the partner should fully fill these criteria. For example, Germany makes a great trade partner with countries that have a better GDP, timeline, landlocked, and distance.

Concerning the extent of international trade competitiveness in service, most of the countries developed various kinds of trade associations with their partners. Both the top 10 upper and lower- performing countries usually had an effective market link or ineffective market link with their partners, based on countries' competitive index. Some of the countries develop an effective or highly effective (competent) link with the partners; whereas, some others develop an uncompetitive or strong uncompetitive link with the importer countries. Especially the inefficient trade link with the developing bilateral trade countries, impose an insufficient problem for countries and also tempt them to compete in the global world. 


\section{References}

[1] Wiegmans BW, Nijkamp P, \& Masurel E (2001) Intermodal Freight Terminals: Marketing Channels and Telecommunication Networks. Transport Reviews, 21: 339-413. DOI: 10.1080/014416401753114260

[2] Banomyong R, Beresford AKC (2001) Multimodal Transport: The Case of Laotian Garments Exporters. International Journal of Physical Distribution and Logistics Management, 31: 668-685. Doi:10.1.1.624.9518

[3] Konings, R., Priemus, H., Nijkamp, P., \& Edward Elgar (2008). The Future of Intermodal Freight Transport. Operations, Design, and Policy. Transport Economics, Management, and Policy. Edward Elgar Publishing Limited, USA. DOI: org/10.1080/00330121003600934

[4] Regan AC, Garrido R (2001) Modeling Freight Demand and Shipper Behavior: State of the Art, Future Directions. Travel Behavior Research, pp 185-215. DOI: 10.1016/B978-008043924-2/50006-7

[5] Tseng Y, Yue LW, \& Taylor P MA (2005) The role of transportation in the logistics chain. Proceedings from the Eastern Asia Society for Transportation Studies, 5: 1657-1672.doi.org/10.32861/jssr.58.1276.1285

[6] Mauro B (2018) Trade Linkages between the Belt and Road Economies. Policy Research Working Paper, 8423, Macroeconomics, Trade, and Investment Global Practice. doi:460281525178627774/WPS8423

[7] Jesudason JV (2020) The Developmental Clienteles State: The Malaysian Case. Humboldt Journal of Social Relations, 23: 147-173. DOI: stable/23263493

[8] Feo-Valero M, Espino-Espino R, \& García-Menéndez L (2011) An stated preference analysis of Spanish freight forwarders modal choice on the South-West Europe Motorway of the Sea. Transport Policy 18: 60-67. DOI: 10.1016/j.tranpol.2010.05.009

[9] Faye ML, McArthur JW, Sachs JD, \& Snow T (2004) Challenges Facing Landlocked Developing Countries. J. Hum. Dev. 5(1):31-68. DOI: 10.1080/14649880310001660201

[10] Henderson J V, Shalizi Z, \& Venables A J (2001) Geography and Development. Journal of Economic Geography, 1: 81-105. DOI: 10.1093/jeg/1.1.81

[11] Rabiy H, Edward K (2016) Analysis of Transport Logistics Challenges Affecting Freight Forwarding Operations in Malawi. African Journal of Business Management, 10: 607-614. DOI: 10.5897/AJBM2016.8218

[12] Arvis J-F, Lauri O, Ojala L, Wiederer C, Shepherd B, Raj A, Dairabayeva K, \& Kiiski T (2018) Connecting to Compete 2018: Trade Logistics in the Global Economy--The Logistics Performance Index and Its Indicators. World Bank, Washington, DC. DOI: 10.1596/29971

[13] Baird A.J (2007) The economics of Motorways of the Sea, Maritime Policy and Management. The flagship journal of international shipping and port research, 34: 287-310. DOI: 10.1080/03088830701538976

[14] Grosso G M, Kyvik NH, Ueno A, Gonzales F, Lejarrage I, Miroudot S, \& Rouzet D (2014) Services Trade Restrictiveness Index (STRI): Transport and Courier Services. OECD Trade Policy Papers, No. 176, OECD, DOI: org/10.1787/5jxt4nd187r6-en

[15] WTO-Economic Research and Statistics Division. https://www.wto.org/english/res_e/reser_e/ersd201114_e.pdf, last accessed 2019/01/17

[16] Hummels D, Schaur G (2012) Time as a Trade Barrier. Cambridge, MA: National Bureau of Economic Research, 103:935-59. DOI: 10.3386/w17758

[17] Hausman HW, Lee LH, \& Subramanian U (2012) Logistics performances can significantly impact bilateral trade relations between trading nations. Production and Operations Management, 22:236-252. DOI:org/10.1111/j.1937-5956.2011.01312.x

[18] The World Economic Forum and the Global Alliance for Trade (2016). http://www3.weforum.org/docs/WEF_GETR_2016_report.pdf, last accessed 2019/03/12

[19] Elena-Daniela (2012). Econometric Estimation of a Gravity Model for the External Trade of Romania. Alexandru Ioan Cuza University of Iaşi, Iaşi, Romania. Journal of Eastern Europe Research in Business and Economics, 2012 (2012), Article ID 854058, 9 pages DOI: 10.5171/2012.854058 